\title{
Hospital Admission and Absence from Work Attributed to Asthma
}

\author{
V. H. SPRINGETT,* M.D., F.R.C.P.
}

Cummary : Study of a $10 \%$ sample of hospital admis$\checkmark$ sions for asthma in England and Wales shows that in each age and sex group deaths have increased by at least a half between 1959 and 1964, while for males aged 15-44 years they have doubled. The number of deaths in hospital has risen in a similar way, and hence the hospital fatality rate has not changed over this period. Since study of certified absences from work has shown no comparable increase, it is suggested that the increase has occurred in the number of attacks of severe asthma requiring admission to hospital.

\section{Hospital Admission}

Recent papers (Smith, 1966 ; Speizer et al., 1968a) have shown that a substantial increase occurred in deaths attributed to asthma in England and Wales between 1960 and 1966. Death is, however, a relatively rare outcome of an attack of asthma, and the recorded increase in deaths could be due to either an increase in this low case fatality or an increase in the incidence of asthma with an unchanged case fatality, or a combination of the two. There is little or no information on the incidence of asthma on a national scale, but some information on the incidence of asthma requiring admission to hospital is available on a country-wide basis from the Hospital In-patient Enquiry (Ministry of Health and General Register Office, 1961-8). This reports annually on a $10 \%$ sample of discharges and deaths from National Health Service hospitals in England and Wales, excluding psychiatric hospitals, and the volumes up to 1965 have been published. The information collected includes, in addition to diagnosis, age, sex, place of residence, department in which treated, source of admission, and duration of stay; for many items "admission rates per 10,000 population" are quoted. The hospital fatality ratio is also given, and this in conjunction with the nurnber in the sample makes it possible to calculate the number of deaths recorded in the $10 \%$ sample.

Table I shows some figures concerning asthma extracted from the volumes for 1959-65. The second column gives the estimate of total admissions each year for asthma, based on the $10 \%$ sample. The total number of admissions fluctuated between 16,400 and 19,400 in the years 1959-62, and then increased progressively by 3,000 to 4,000 per year to reach a total of just over 30,000 in 1965 , not quite double the figure for 1959. Table I also shows that this substantial increase in admissions has not been accompanied by any great change in

\begin{tabular}{|c|c|c|c|c|c|c|c|c|c|}
\hline & \multirow{3}{*}{$\begin{array}{c}\text { Esti- } \\
\text { mated } \\
\text { Total } \\
\text { Admis- } \\
\text { sions per } \\
\text { Year } \\
\text { Patients }\end{array}$} & \multirow{2}{*}{\multicolumn{2}{|c|}{$\begin{array}{l}\text { Mean } \\
\text { Duration } \\
\text { of Stay } \\
\text { per Spell } \\
\text { (Days) }\end{array}$}} & \multirow{2}{*}{\multicolumn{2}{|c|}{$\begin{array}{l}\text { Immediate } \\
\text { Admissions } \\
(\%)\end{array}$}} & \multicolumn{4}{|c|}{$\begin{array}{l}\text { Distribution by Department } \\
\text { of } 10 \% \text { Sample }\end{array}$} \\
\hline & & & & & & \multirow{2}{*}{$\begin{array}{l}\text { Gen. } \\
\text { Med. } \\
(\%)\end{array}$} & \multirow{2}{*}{$\begin{array}{c}\text { Paed. } \\
(\%)\end{array}$} & \multirow{2}{*}{$\begin{array}{l}\text { Dis. } \\
\text { Chest } \\
(\%)\end{array}$} & \multirow{2}{*}{$\begin{array}{l}\text { Other } \\
(\%)\end{array}$} \\
\hline & & $M$ & F & $M$ & $\mathrm{~F}$ & & & & \\
\hline $\begin{array}{l}1959 \\
1960 \\
1961 \\
1962 \\
1963 \\
1964 \\
1965\end{array}$ & $\begin{array}{l}16,400 \\
17,970 \\
19,340 \\
18,580 \\
23,314 \\
26,257 \\
30,034\end{array}$ & $\begin{array}{l}17 \cdot 7 \\
17 \cdot 2 \\
17 \cdot 1 \\
16 \cdot 7 \\
18 \cdot 7 \\
18 \cdot 1\end{array}$ & $\begin{array}{l}16 \cdot 9 \\
15 \cdot 2 \\
17 \cdot 9 \\
16 \cdot 3 \\
18 \cdot 1 \\
18 \cdot 0\end{array}$ & $\begin{array}{l}87 \\
84 \\
90 \cdot 5 \\
89 \cdot 4 \\
91 \cdot 3 \\
\end{array}$ & $\begin{array}{l}86 \\
86 \\
90 \cdot 5 \\
92 \cdot 6 \\
89 \cdot 5 \\
\end{array}$ & $61 \cdot 8$ & $15 \cdot 5$ & $12 \cdot 6$ & $6 \cdot 7$ \\
\hline
\end{tabular}

* Consultant Chest Physician, Birmingham Chest Clinic. the mean duration of stay, though this has increased slightly. Throughout the period under review the great majority of admissions were classified as immediate, from $84 \%$ to $93 \%$ being in this category. This item was not published for the years 1961 and 1965 .

The last part of Table I shows that there has been some change in the departments to which cases of asthma have been admitted. This information has been published only for 1959 and 1964 ; in both of these years more than half the patients with asthma were admitted to general medical departments, though the proportion fell from $61 \cdot 8 \%$ to $56 \cdot 3 \%$. There was a substantial increase in the proportion admitted to departments of chest diseases from $12.6 \%$ to $21.4 \%$. The increasing proportion admitted to departments of chest diseases is no doubt due to the increasing number of beds available for the treatment of non-tuberculous respiratory disease in these departments as the number of beds required for the treatment of tuberculosis declines. However, relating the percentages in the right-hand part of Table I to the estimated totals in column 2 shows that this increased proportion of admissions to departments of chest disease does not account for the increase in admissions of asthma, since the number of asthma admissions to departments of general medicine alone increased between 1959 and 1964 from approximately 10,000 to about 15,000.

Further indications that the increase of asthma admissions in recent years is a real one is shown by comparison with the changes that have occurred for other causes of admission (not tabulated here). Between 1960 and 1965 there was a slight decrease in the admission rates for pneumonia, and an increase of $22 \%$ in the admission rates for males with bronchitis; the increase for asthma in males was $76 \%$. In females the increase in admissions for bronchitis was $20 \%$, but asthma admissions increased by $50 \%$ between 1960 and 1965 .

Table II shows estimated hospital admission rates for asthma per 10,000 population for four broad age groups of each sex for each year 1959-65. The absolute numbers in the $10 \%$ samples on which these figures are based are of reasonable size, being between 100 and 500 except for females aged 5-14 years in the years 1959-62, for which they lie between 90 and 100 , and for males age 65 and over in all years, for which they are between 70 and 100 .

TABLE II.-Asthma: Estimated Hospital Admission Rates per 10,000 Population; Age Groups of Each Sex for Each Year 1959-65

\begin{tabular}{|c|c|c|c|c|c|c|c|c|}
\hline \multirow{2}{*}{$\begin{array}{l}\text { Age group } \\
\text { (years): }\end{array}$} & \multicolumn{4}{|c|}{ Males } & \multicolumn{4}{|c|}{ Females } \\
\hline & $5-$ & $15-$ & 45 & 65 & $5-$ & $15-$ & 45 & $65-$ \\
\hline $\begin{array}{l}1959 \\
1960 \\
1961 \\
1962 \\
1963 \\
1964 \\
1965\end{array}$ & $\begin{array}{l}4 \cdot 4 \\
4 \cdot 0 \\
5 \cdot 4 \\
4 \cdot 4 \\
6 \cdot 0 \\
7 \cdot 3 \\
7 \cdot 7\end{array}$ & $\begin{array}{l}2 \cdot 0 \\
2 \cdot 1 \\
2 \cdot 5 \\
2 \cdot 2 \\
3 \cdot 1 \\
3 \cdot 6 \\
4 \cdot 1\end{array}$ & $\begin{array}{l}4 \cdot 0 \\
4 \cdot 1 \\
4 \cdot 3 \\
4 \cdot 1 \\
5 \cdot 6 \\
6 \cdot 2 \\
7 \cdot 0\end{array}$ & $\begin{array}{l}3 \cdot 3 \\
3 \cdot 6 \\
3 \cdot 6 \\
4 \cdot 3 \\
4 \cdot 6 \\
4 \cdot 1 \\
5 \cdot 8\end{array}$ & $\begin{array}{l}2 \cdot 9 \\
2 \cdot 9 \\
2 \cdot 8 \\
3 \cdot 1 \\
3 \cdot 4 \\
4 \cdot 8 \\
5 \cdot 3\end{array}$ & $\begin{array}{l}3 \cdot 7 \\
4 \cdot 0 \\
4 \cdot 2 \\
4 \cdot 4 \\
4 \cdot 8 \\
5 \cdot 6 \\
5 \cdot 8\end{array}$ & $\begin{array}{l}5 \cdot 3 \\
6 \cdot 0 \\
5 \cdot 8 \\
6 \cdot 0 \\
7 \cdot 5 \\
8 \cdot 3 \\
9 \cdot 0\end{array}$ & $\begin{array}{l}3 \cdot 3 \\
4 \cdot 1 \\
4 \cdot 2 \\
3 \cdot 9 \\
4 \cdot 8 \\
4 \cdot 3 \\
6 \cdot 1\end{array}$ \\
\hline $\begin{array}{c}\% \text { Increase } \\
1959-65\end{array}$ & 75 & 105 & 75 & 76 & 48 & 57 & 70 & 85 \\
\hline
\end{tabular}

Table II repeats the general tendency for asthma admission rates to increase, and during the period from 1959 to 1965 the admission rates for age groups of males have increased by 75 to $100 \%$, those for females by from 50 to $85 \%$. Table II also shows an excess of asthma admissions in young males 
compared with females, as the admission rate for males aged 5-14 years exceeds that for females by at least $25 \%$ in each year; there is a higher admission rate in females than males at ages 15-44 years and 45-64 years. The main point, however, for the present purpose is that in each age group the admission rates have increased by at least $50 \%$ between 1959 and 1965 , and they have doubled in this period for males aged 15-44 years.

Table III shows the number of deaths in the $10 \%$ sample of admissions for asthma for each year 1959-65, for the age group 5-44 years. The numbers are extremely small and show considerable fluctuation, but taking both sexes together the mean number of deaths in the sample was 8.4 for the years 1959-61 and 19 for the years 1964-65, rather more than double the earlier period. During this period recorded deaths from asthma for the whole country for the age group 5-34 years increased from a mean of 140 in 1959-61 to 248 in 1964-5. If allowance is made for the different age grouping the increase in all deaths is therefore similar to the increase in hospital deaths as shown by the rather small sample number. Hospital admissions for asthma rose by roughly the same amount during this period, so that it follows that there has been no appreciable change in the hospital fatality ratio during the period under review.

TABLE III.-Number of Deaths in Hospital Attributed to Asthma in

\begin{tabular}{|c|c|c|c|}
\hline & Males & Females & Total \\
\hline $\begin{array}{l}1959 \\
1960 \\
1961 \\
1962 \\
1963 \\
1964 \\
1965\end{array}$ & $\begin{array}{r}3 \\
3 \\
5 \\
4 \\
2 \\
11 \\
9\end{array}$ & $\begin{array}{r}5 \\
2 \\
7 \\
2 \\
9 \\
8 \\
10\end{array}$ & $\begin{array}{r}8 \\
5 \\
12 \\
6 \\
11 \\
19 \\
19\end{array}$ \\
\hline
\end{tabular}

\section{Absence from Work}

In the Annual Reports of the Ministry of Pensions and National Insurance (1960-6) and the Ministry of Social Security 1967-8) claims for national insurance are analysed by the certified cause of absence. This information covers only the age groups of insured working life (15-64 years), and since 1964 no analysis by cause has been given for females. Table IV shows for males the number of spells of absence attributed to asthma starting in the period stated (the total spells current

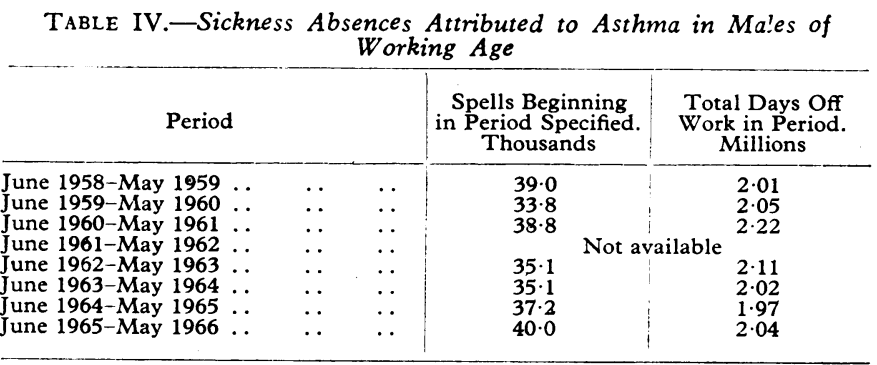

at some time in any year are about 5,000 to 6,000 greater owing to "carry over" from the previous year) and the total days off work in each yearly period.

There is no evidence at all of any recent increase in the total number of days off work owing to asthma: the highest figure of all, 2.22 million days, occurred in 1960-1, and the total then fell to within 0.04 of 2 million days for each of the years in the period 1963-6. The number of spells of absence beginning in each period fell from $38 \cdot 8$ thousand to $35 \cdot 1$ thousand between $1960-1$ and 1962-3, was unchanged in 1963-4, but then increased to $37 \cdot 2$ thousand in $1964-5$ and to $40 \cdot 0$ thousand in 1966-7. These changes are quite in keeping with the fluctuations observed in previous years, but could represent a rising trend since $1963-4$. If so, the increase is of only $13.5 \%$, very much less than that recorded for hospital admissions for asthma, and for deaths.

\section{Discussion}

Hospital admissions for asthma increased substantially between 1960 and 1965, roughly parallel to the previously recorded increase in deaths attributed to asthma. Certified absences from work due to asthma have shown no similar increase, though a much smaller increase may have occurred between 1963 and 1966. This relatively constant level of absence from work owing to asthma tends to confirm the observations from general practice recorded by Speizer et al. (1968b).

The general picture therefore appears to be of an increased number of attacks of severe asthma, requiring admission to hospital, and an increase in deaths, but with no increase in the overall number of episodes of asthma requiring medical care or of certified absence from work.

Unfortunately, it is not possible to determine whether the increase in hospital admissions recorded here is due to an increased number of admissions from a constant number of asthmatics or to an increase in the number of persons with asthma ; nor can the cause of the increased number of admissions be deduced. The possible causes for the increase in deaths have been fully discussed by Speizer et al. (1968a), and the same considerations are likely to apply to the increase in hospital admissions.

It is a pleasure to acknowledge the helpful comments made by Dr. R. Doll and Dr. J. M. Smith after reading a preliminary draft of this paper.

\section{REFERENCES}

Ministry of Health and General Register Office (1961-8). Reports on Hospital In-patient Enquiry for the years 1959, 1960, 1961, 1962, 1963, 1964, 1965. H.M.S.O., London.

Ministry of Pensions and National Insurance (1960-6). Annual Reports for the years 1959-1965. H.M.S.O., London.

Ministry of Social Security (1967-8). Annual Reports for the years 1966-1967. H.M.S.O., London.

Speizer, F. E., Doll, R., and Heaf, P. (1968a). Brit. med. F., 1, 335

Speizer, F. E., Doll, R., Heaf, P., and Strang, L. B. (1968b). Brit. med. F., 1, 339 . 